\title{
Hubungan Obesitas pada Pra Lansia dengan Kejadian Hipertensi di Kecamatan Senen Jakarta Pusat Tahun 2017-2018
}

\author{
${ }^{1}$ Juwita Kartika, ${ }^{2}$ Endang Purwaningsih \\ ${ }^{1,2}$ Pendidikan Kedokteran Fakultas Kedokteran Universitas YARSI \\ Jl. Letjend Suprapto No.1, Cemp. Putih Tim., Kec. Cemp. Putih, Jakarta Pusat 10510 \\ Email : jkartika96@yahoo.com
}

\begin{abstract}
ABSTRAK
Hipertensi merupakan masalah kesehatan global termasuk Indonesia. Prevalensi hipertensi akan meningkat dengan bertambahnya usia. Hipertensi mempunyai berbagai macam faktor risiko dimana salah satunya adalah obesitas. Pemeriksaan yang digunakan dalam menentukan obesitas adalah indeks massa tubuh. Tujuan penelitian adalah mengetahui hubungan obesitas pada pra lansia dengan kejadian hipertensi di Kecamatan Senen Jakarta Pusat Tahun 2017-2018 dan tinjauannya dari sisi Islam. Penelitian ini dilakukan dengan pendekatan survey analitik secara cross sectional. Jumlah sampel penelitian 100 subjek dan pengambilan sampel dengan teknik cluster sampling. Pengukuran yaitu tekanan darah sistolik dan diastolik, tinggi badan, dan berat badan. Analisis data dilakukan dengan uji Chi-square. Hasil penelitian menunjukkan angka kejadian hipertensi pada pra lansia adalah 65 orang (65\%) dan terdapat hubungan yang bermakna antara obesitas pada pralansia dengan kejadian hipertensi ( $\mathrm{p}=0,029, \mathrm{OR}=2,53$ ). Disimpulkan bahwa obesitas berhubungan dengan kejadian hipertensi pada pra lansia dengan risiko 2,53 kali lebih besar dibandingkan dengan tidak obesitas.
\end{abstract}

Kata Kunci: Hipertensi, obesitas, pralansia, indeks massa tubuh

\begin{abstract}
ABSTRAK
Hypertension is a global health problem including Indonesia. The prevalence of hypertension will increase with age. One of the risk factors of hypertension is obesity. The examination used to determine obesity is a body mass index. This study aims to determine the relationship obesity preelderly with hypertension in senen sub-district central jakarta of 2017-2018 and the review of islam side. This research was conducted by analytical survey approach by cross sectional. Sampling method with cluster sampling technique and sample amount of 100 subjects. Measurements include systolic and diastolic blood pressure, weight, and height. The data were analysis by Chi-square test. The results showed that the incidence of hypertension in pre-elderly was 65 people $(65 \%)$ and there was a significant relationship between obesity in pre-elderly with hypertension $(p=0,029$, OR $=2,53)$. ). It was concluded that obesity was associated with the incidence of hypertension in pre- elderly with a risk of 2.53 times greater than those who were not obesity.
\end{abstract}

Keywords: Hypertension, obesity, pre-elderly, body mass index 


\section{Pendahuluan}

Tekanan darah tinggi (hipertensi) menjadi permasalahan kesehatan global termasuk Indonesia. Dalam pedoman JNC VII, tekanan darah terbilang tinggi (hipertensi) jika tekanan darah mencapai leih dari sama dengan 140/90 mmHg. Seseorang yang mengalami tekanan darah tinggi (hipertensi) tidak akan merasakan keluhan yang khas yang menyebabkan penderita tidak sadar dan tidak melakukan kontrol serta berobat teratur. Selain itu masih adanya pengetahuan yang kurang tentang faktor risiko dari meningkatnya tekanan darah..$^{(1,2)}$

Setelah Tuberkulosis dan Stroke, Hipertensi merupakan penyebab kematian terbesar yaitu sebanyak 6,7\% di Indonesia. Prevalensinya meningkat seiring dengan gaya hidup yang memburuk seperti rokok, tidak melakukan aktivitas fisik, dan stres. Berdasarkan data RISKESDAS tahun 2013, hipertensi di Indonesia mencapai 26,5\%. Di DKI Jakarta menunjukkan bahwa adanya peningkatan hipertensi sesuai dengan usia, terlihat mulai dari pralansia 45 tahun dengan prevalensi sebesar 31,9\% dibandingkan dengan usia 35 tahun sebesar 21,2\%. Angka hipertensi di Jakarta Pusat masih sangat tinggi yaitu $20,0 \% .^{(3,4)}$

Berdasarkan laporan Riskesdas Provinsi DKI Jakarta tahun 2013 bahwa prevalensi tertinggi obesitas menurut IMT dan karakteristik kelompok umur dialami oleh usia pra lansia, yaitu mulai dari usia 45 tahun pada pria sebesar $22,8 \%$ dan wanita yaitu $37,6 \% .^{(4,5)}$

Dalam The Framingham Heart Study disebutkan terdapat hubungan yang kuat antara obesitas dengan tekanan darah tinggi, pada wanita sebesar $65 \%$ faktor risiko hipertensi berkaitan dengan obesitas semestara pada pria sebesar $78 \%$. Pada penderita obesitas, terdapat beberapa mekanisme patofisiologi yang melibatkan aktivasi sistem saraf simpatis dan sistem renin angiolensin-aldosteron (RAA). ${ }^{(6)}$

DKI Jakarta terutama Jakarta Pusat memiliki angka prevalensi hipertensi yang masih tinggi. Puskesmas Senen merupakan Puskesmas yang berada di Jakarta Pusat. Penderita hipertensi pralansia pada tahun 2017 di Puskesmas Senen dari bulan Januari sampai November sebesar 624 kasus sedangkan obesitas sebesar 478 kasus. Hal ini menunjukkan obesitas mungkin dapat memicu peningkatan kasus penderita hipertensi di Kecamatan Senen. Penelitian ini bertujuan untuk diketahuinya hubungan obesitas pada pra lansia dengan kejadian hipertensi di Kecamatan Senen Jakarta Pusat Tahun 20172018.

\section{Metode Penelitian}

Desain studi penelitian ini adalah crosssectional. Populasi penelitian ini adalah penduduk pra lansia di Kecamatan Senen dengan jumlah sampel 100 orang yang memenuhi kriteria inklusi yaitu usia pralansia 45-59 tahun, dan kriteria eksklusinya yaitu orang yang tidak bersedia menjadi responden. Pengambilan sampel dilakukan pada satu posbindu di setiap kelurahan yang ada di Kecamatan Senen sampai memenuhi 100 sampel responden dengan teknik cluster sampling. Data primer didapatkan dengan pengukuran tekanan darah dan pengukuran 
IMT secara langsung. Data dianalisa dengan uji chi-square menggunakan software analisis statistik.

\section{Hasil}

\section{Gambaran}

Umum

Penelitian

Kecamatan Senen yang terletak di Jakarta Pusat memiliki 6 kelurahan dan 27 posbindu. Penelitian ini dilakukan pada satu posbindu di setiap kelurahan di Kecamatan Senen Jakarta Pusat sehingga ada 6 posbindu yang menjadi tempat lokasi penelitian sampai memenuhi 100 sampel responden.

\section{Karakteristik Data Responden}

Dari Tabel 1 di atas dapat disimpulkan bahwa usia responden diketahui terbanyak yaitu kelompok usia 50-54 tahun sebanyak 39 responden (39\%) dan yang paling sedikit berada pada kelompok usia 45-49, yaitu hanya 26 responden (26\%). Sedangkan distribusi keseluruhan responden yang obesitas berjumlah 52 orang (obesitas I ada 40 orang dan obesitas II ada 12 orang) dan yang tidak obesitas berjumlah 48 orang (48\%).

Tabel 1. Karakteristik Responden

\begin{tabular}{ccc}
\hline $\begin{array}{c}\text { Karakteristik } \\
\text { Responden }\end{array}$ & $\begin{array}{c}\text { Frekuensi } \\
(\mathbf{n})\end{array}$ & $\begin{array}{c}\text { Persentase } \\
(\mathbf{\%})\end{array}$ \\
\hline $45-49$ & 26 & 26,0 \\
$50-54$ & 39 & 39,0 \\
$55-59$ & 35 & 35,0 \\
\hline Obesitas I & 40 & 40,0 \\
Obesitas II & 12 & 12,0 \\
Tidak & 48 & 48,0 \\
Obesitas & & 100,0 \\
\hline Total & 100 & \\
\hline
\end{tabular}

\section{Status Tekanan Darah}

Dari Tabel 2 terlihat responden yang menderita hipertensi berjumlah 65 orang sedangkan yang tidak hipertensi, yaitu berjumlah 35 orang (35\%).

Tabel 2. Distribusi Responden Berdasarkan Kategori Tekanan Darah di Kecamatan Senen Jakarta Pusat

\begin{tabular}{ccc}
\hline Tekanan Darah & $\begin{array}{c}\text { Frekuensi } \\
(\mathbf{n})\end{array}$ & $\begin{array}{c}\text { Persentase } \\
(\mathbf{\%})\end{array}$ \\
\hline Hipertensi Tahap 1 & 38 & 38,0 \\
Hipertensi Tahap 2 & 27 & 27,0 \\
Tidak Hipertensi & 35 & 35,0 \\
\hline Total & 100 & 100,0 \\
\hline
\end{tabular}

\section{Hubungan Obesitas pada Pralansia dengan Hipertensi}

Pada Tabel 4, dari hasil analisis dapat diketahui bahwa ada hubungan yang signifikan antara obesitas pada pralansia dengan kejadian hipertensi di Kecamatan Senen Jakarta Pusat Tahun 2017-2018 (p<0,05). OR diketahui sebesar 2,53, yang menyimpulkan orang yang mengalami obesitas berisiko terkena hipertensi sebesar 2 kali. Hasil penelitian didapatkan 65 orang mengalami hipertensi, 39 orang diantaranya obesitas dan 26 orang diantaranya tidak obesitas. Dari 52 orang yang obesitas, 39 diantaranya hipertensi dan 13 orang tidak hipertensi. 
Tabel 4. Hubungan Obesitas pada Pralansia dengan Kejadian Hipertensi

\begin{tabular}{|c|c|c|c|c|c|}
\hline & \multicolumn{2}{|c|}{ Tekanan Darah } & \multirow[b]{2}{*}{ Total } & \multirow[b]{2}{*}{ p-value } & \multirow{2}{*}{$\begin{array}{c}\text { OR } \\
(95 \% \mathrm{Cl})\end{array}$} \\
\hline & Hipertensi & $\begin{array}{c}\text { Tidak } \\
\text { Hipertensi }\end{array}$ & & & \\
\hline Obesitas & $\begin{array}{c}39 \\
(75,0 \%)\end{array}$ & $\begin{array}{c}13 \\
(25,0 \%)\end{array}$ & $\begin{array}{c}52 \\
(100,0 \%)\end{array}$ & 0,029 & 2,53 \\
\hline Tidak obesitas & $\begin{array}{c}26 \\
(54,2 \%)\end{array}$ & $\begin{array}{c}22 \\
(45,8 \%)\end{array}$ & $\begin{array}{c}48 \\
(100,0 \%)\end{array}$ & & \\
\hline Total & 65 & 35 & $100,0 \%$ & & \\
\hline
\end{tabular}

\section{Pembahasan}

Angka kejadian hipertensi pra lansia (45-59 tahun) dari hasil penelitian ini cukup tinggi, yaitu 65 responden (65\%). Sejalan dengan penelitian Haskas dan Puspita tahun 2014 yang menyimpulkan bahwa dari 37 responden, responden yang hipertensi lebih banyak pada usia $\geq 45$ tahun yaitu sebanyak 28 orang sedangkan yang usia $<45$ tahun yaitu hanya 9 orang. ${ }^{(7)}$ Penelitian ini juga diperkuat oleh penelitian Apriyadi tahun 2010 yang menyatakan bahwa angka hipertensi terbanyak pada usia >45 tahun, yaitu 43 responden $(74,1 \%)$ dibandingkan dengan usia $<45$ tahun, yaitu 15 responden $(35,7 \%)$. Hal itu mungkin disebabkan karena pada saat seseorang berusia $>45$ tahun dinding arteri mengalami penebalan yang menyebabkan pembuluh darah mengalami penyempitan secara perlahan dan menjadi kaku sehingga menyebabkan hipertensi. Selain itu, prevalensi hipertensi akan meningkat dengan bertambahnya usia dan terlihat mulai dari usia pralansia 45 tahun. ${ }^{(8)}$

Hasil analisis penelitian menyimpulkan bahwa ada hubungan yang bermakna pada obesitas terhadap hipertensi. Dari 65 responden yang mengalami hipertensi, 39 orang diantaranya obesitas. Hasil penelitian ini sejalan dengan penelitian yang telah dilakukan Sulastri dkk tahun 2012 bahwa dari 102 orang yang hipertensi, sebanyak 64 orang adalah obesitas. Hal ini disebabkan karena pada Etnis Minangkabau mempunyai makanan tradisional, yaitu rendang dimana bahan utama membuat rendang adalah minyak kelapa dan santan yang merupakan sumber utama kaya asam lemak jenuh dan sebanyak $95 \%$ orang kurang memakan buah dan sayur. Orang yang obesitas memiliki peluang 1,82 kali lebih besar untuk terjadi nya tekanan darah tinggi..$^{(9)}$

Penelitian lain yang telah dilakukan oleh Kembuan dkk tahun 2015, mengahasilkan kesimpulan bahwa ada hubungan yang bermakna antara obesitas dengan kejadian tekanan darah tinggi $(\mathrm{OR}=3,48)$. Ini disebabkan karena terjadi peningkatan kinerja jantung pada orang yang mengalami obesitas sehingga volume darah dan tekanan pada dinding arteri semakin besar. Penelitian ini menyimpulkan orang yang obesitas lebih sering mengalami hipertensi (39 orang : 13 orang). ${ }^{(10)}$ Hasil penelitian ini sama dengan yang dilakukan oleh Lasianjayani dan Martini pada 2014 yang menyimpulkan bahwa dari 29 orang yang obesitas, 23 diantaranya mengalami hipertensi dan hanya 6 orang tidak hipertensi. Terdapat hubungan yang signifikan antara obesitas dengan hipertensi di RSU Haji Surabaya. ${ }^{(11)}$ 
Obesitas dapat menjadi faktor risiko dari hipertensi pada pralansia. Pada penelitian ini didapatkan responden yang hipertensi lebih sering terjadi pada responden obesitas bila dibandingkan dengan responden yang tidak obesitas. Hasil penelitian ini sejalan dengan penelitian yang telah dilakukan oleh Madhe dan Wayan tahun 2013 di wilayah kerja Puskesmas Dawan I. Tekanan darah tinggi banyak ditemukan pada kelompok yang mengalami obesitas dibandingkan pada responden yang indeks massa tubuhnya normal dan overweight. Sehingga obesitas menjadi salah satu risiko tekanan darah tinggi. ${ }^{(12)}$ Pada penelitian Olack et al., (2015) mengenai faktor risiko hipertensi dan hubungannya dengan hipertensi pada usia rata-rata 46,7 tahun di Nairobi, Kenya mendapatkan bahwa prevalensi hipertensi berbeda secara signifikan antara obesitas dan individu tidak obesitas $(36,0 \%$ dan $25,8 \%, p<0,001){ }^{(13)}$

\section{Kesimpulan}

Angka kejadian hipertensi pada pralansia di Kecamatan Senen Jakarta Pusat adalah 65 orang (65\%). Terdapat hubungan bermakna antara obesitas pada pra lansia dengan kejadian hipertensi di Kecamatan Senen Jakarta Pusat Tahun 2017-2018.

\section{Saran}

Bagi subyek penelitian dan masyarakat untuk dapat menerapkan pola hidup sehat seperti makan gizi seimbang, melakukan kegiatan fisik seperti olahraga teratur (jogging, lari, bersepeda minimal selama 20 menit dengan frekuensi minimal 3 kali dalam seminggu) dan bisa mengontrol berat badan sehingga dapat terhindar dari obesitas.

\section{Daftar Pustaka}

1. Chobanian, A.V., Bakris, G.L., Black, H.R., Cushman, W.C., Green, L.A., Izzo, J.L. et al. 2003. The Seventh Report of Joint National Committee on Prevention, Detection, Evaluation, and Treatment of High Blood Pressure: The JNC 7 Report. The Journal of the American Medical Association: 1-5.

2. Rilantono, L.I. 2012. Penyakit Kardiovaskular $(P K V)$. Editor: Karo, Santoso, dkk. Jakarta: Badan Penerbit FKUI.

3. Depkes RI. 2010. Hipertensi penyebab kematian nomor tiga. Kementerian Kesehatan RI. Jakarta.

4. Balitbang Kemenkes RI. 2013. Riset Kesehatan Dasar;RISKESDAS. Jakarta: Balitbang Kemenkes RI.

5. Ren, Q., Su, C., Wang, H., Wang, Z., Du, W. and Zhang, B. 2016. Change in body mass index and its impact on incidence of hypertension in 18-65-year-old Chinese adults. International Journal of Environmental Research and Public Health 13(3).

6. Natalia, D., Hasibuan,P., dan Hendro. 2015. Hubungan Obesitas dengan Kejadian Hipertensi di Kecamatan Sintang, Kalimantan Barat. $\quad C D K$ 42(5): 336- 339. 
7. Puspita, E. dan Haskas, Y. 2014. Faktor Risiko Kejadian Hipertensi Pada Pasien Yang Berobat Di Poliklinik Rumah Sakit Umum Daerah Labuang Baji Makassar. Jurnal Ilmiah Kesehatan Diagnosis 5(1).

8. Apriyandi, F. 2010. Hubungan Antara Peningkatan Usia Dengan Kejadian Hipertensi Pada Pasien Yang Berobat Jalan Di Rumah Sakit Bhineka Bakti Husada Pada Tanggal 19 Sampai 31 Juli 2010. Skripsi. Jakarta: Fakultas Kedokteran Universitas Islam Negeri Syarif Hidayatullah.

9. Sulastri, D., Elmatris., dan Ramadhani, R. 2012. Hubungan Obesitas Dengan Kejadian Hipertensi Pada Masyarakat Etnik Minangkabau Di Kota Padang. Majalah Kedokteran Andalas 36(2): 188199.

10. Kembuan, I. Y., Kandou, G. dan Kaunang, W. P. J. 2015. Hubungan
Obesitas dengan Penyakit Hipertensi pada Pasien Poliklinik Puskesmas Touluaan Kabupaten Minahasa Tenggara. Jurnal Paradigma 4(2): 16-35.

11. Lasianjayani, T. dan Martini, S. 2014. Hubungan antara Obesitas dan Perilaku Merokok terhadap Kejadian Hipertensi. Jurnal Berkala Epidemiologi 2(3): 286296.

12. Madhe dan Wayan. 2013. Gambaran Faktor Risiko Hipertensi Pada Masyarakat Pralansia di Wilayah Kerja Puskesmas Dawan I Periode Mei 2013. Skripsi. Fakultas Kedokteran Udayana.

13. Olack, B., Mangen, F.W., Smeeth, L., Montgomery,J.M., Kiwanuka, N. and Breiman, R.F. 2015. Risk factors of hypertension among adults aged 35-64 years living in an urban slum Nairobi, Kenya. BMC Public Health 15(1): 1-10.

14 